\section{SAT0313 ILEAL BUT NOT COLONIC INFLAMMATION IS LINKED TO FATTY LESIONS ON MRI OF THE SACROILIAC JOINTS IN SPONDYLOARTHRITIS PATIENTS}

${ }_{1,2}$ Ann-Sophie De Craemer, Manouk de Hooge ${ }^{1,2}$, Thomas Renson ${ }^{1,2}$, Liselotte Deroo ${ }^{1,2}$, Triana Lobaton Ortega ${ }^{3}$, Anne Hoorens ${ }^{4}$, Philippe Carron ${ }^{1,2}$ Filip van den Bosch ${ }^{1,2}$, Dirk Elewaut ${ }^{1,2}$, Be-Giant consortium. ${ }^{1}$ Ghent University Hospital, Rheumatology, Ghent, Belgium; ${ }^{2}$ VIB Inflammation Research Center, Ghent, Belgium; ${ }^{3}$ Ghent University Hospital, Gastrenterology, Ghent, Belgium; ${ }^{4}$ Ghent University Hospital, Pathology, Ghent, Belgium

Background: Gut and joint inflammation in spondyloarthritis $(\mathrm{SpA})$ are closely intertwined. About $50 \%$ of axial SpA patients display microscopic signs of inflammation in ileum and/or colon, a risk factor to develop Crohn's disease over time. It is currently not known if presence of microscopic gut inflammation in new onset $\mathrm{SpA}$ is associated with more structural lesions on magnetic resonance imaging of the sacroiliac joints (MRI$\mathrm{SIJ})$ and whether these lesions relate to the localization of gut inflammation.

Objectives: To assess whether structural lesions on MRI-SIJ (A) are associated with microscopic gut inflammation in SpA patients and (B) are preferably related to colon or ileum inflammation in case of gut involvement.

Methods: We analyzed baseline information from the Be-Giant cohort, a registry of SpA patients fulfilling the Assessment of SpondyloArthritis international Society (ASAS) classification criteria for axial or peripheral SpA. MRI-SIJ was scored by 3 readers, blinded for subject characteristics. Six consecutive slices were assessed for structural lesions: sclerosis, erosions, fatty lesions and (partial) ankylosis. MRI sum scores were analyzed as 2 out of 3 (median) scores. Colon and ileum biopsies were evaluated for microscopic signs of inflammation. The effect of gut inflammation (colon and/or ileum) on MRI-SIJ lesions was investigated by generalized linear models (GLM), adjusted for age and gender and stratified for the SpA phenotype.

Results: By January 2019, baseline data were available on 105 patients (95 axial and 10 peripheral SpA). Gut inflammation was present in 35 patients (17 ileum, 8 colon, 10 both). Table 1 shows the slope $\left(\beta_{1}\right)$ of the GLMs for erosions, fatty lesions, sclerosis and (partial) ankylosis and the p-value for the SpA phenotype as an interaction term. Erosions, sclerosis, nor ankylosis show a significant association with gut inflammation in general. If present, colon inflammation has no significant relationship with each individual structural lesion. In contrast, presence of ileum inflammation was associated with an increase in the number of fatty lesions by $0,68(95 \% \mathrm{Cl} 0,04-1,38)$. All results are independent of the $\mathrm{SpA}$ phenotype $(p>0,05)$.

Conclusion: lleal but not colonic inflammatory gut lesions are linked to more fatty lesions on MRI-SIJ in newly diagnosed SpA patients. Baseline microscopic gut inflammation was not associated with erosions, sclerosis nor ankylosis. These data support the concept that microscopic gut inflammation, especially ileal inflammation, is associated with more severe axial inflammation in SpA.

Table 1. Association between MRI-SIJ structural lesions and gut inflammation in SpA patients.

\begin{tabular}{|c|c|c|c|c|c|}
\hline $\begin{array}{l}\text { Structural } \\
\text { lesion }\end{array}$ & $\begin{array}{c}\text { Gut } \\
\text { inflammation }\end{array}$ & $\beta_{1}$ & $95 \% \mathrm{Cl}$ & $\begin{array}{c}\mathrm{p}- \\
\text { value }\end{array}$ & $\begin{array}{c}\mathrm{p} \text {-value interaction } \\
\text { term }^{\star}\end{array}$ \\
\hline & $\begin{array}{l}\text { Colon and/or } \\
\text { ileum }\end{array}$ & 0,02 & $\begin{array}{c}(-0,39- \\
0,45)\end{array}$ & 0,92 & 0,53 \\
\hline \multirow[t]{3}{*}{ Erosions } & Colon & $-0,08$ & $\begin{array}{c}(-0,56- \\
0,45)\end{array}$ & 0,75 & 0,50 \\
\hline & Ileum & $-0,01$ & $\begin{array}{c}(-0,47- \\
0,46)\end{array}$ & 0,94 & 0,66 \\
\hline & $\begin{array}{l}\text { Colon and/or } \\
\text { ileum }\end{array}$ & 0,38 & $\begin{array}{c}(-0,23- \\
1,04)\end{array}$ & 0,22 & 0,61 \\
\hline \multirow[t]{3}{*}{ Fatty lesions } & Colon & $-0,54$ & $\begin{array}{c}(-1,28- \\
0,30)\end{array}$ & 0,16 & 0,94 \\
\hline & Ileum & 0,68 & $\begin{array}{c}(0,04- \\
1,38)\end{array}$ & 0,04 & 0,88 \\
\hline & $\begin{array}{l}\text { Colon and/or } \\
\text { ileum }\end{array}$ & $-0,19$ & $\begin{array}{c}(-0,60- \\
0,23)\end{array}$ & 0,35 & 0,81 \\
\hline \multirow[t]{2}{*}{ Sclerosis } & Colon & 0,05 & $\begin{array}{c}(-0,45- \\
0,60)\end{array}$ & 0,84 & 0,60 \\
\hline & Ileum & $-0,27$ & $\begin{array}{c}(-0,68- \\
0,17)\end{array}$ & 0,22 & 0,62 \\
\hline (Partial) & $\begin{array}{l}\text { Colon and/or } \\
\text { ileum }\end{array}$ & $-0,38$ & $\begin{array}{c}(-1,14- \\
0,44)\end{array}$ & 0,35 & 0,41 \\
\hline \multirow[t]{2}{*}{ Ankylosis } & Colon & $-0,40$ & $\begin{array}{c}(-1,33- \\
0,76)\end{array}$ & 0,45 & 0,60 \\
\hline & Ileum & $-0,24$ & $\begin{array}{c}(-1,05- \\
0,68) \\
\end{array}$ & 0,58 & 0,40 \\
\hline
\end{tabular}

* $\mathrm{SpA}$ subtype (axial versus peripheral $\mathrm{SpA}$ ) as an interaction term.
Disclosure of Interests: Ann-Sophie De Craemer: None declared, Manouk de Hooge: None declared, Thomas Renson: None declared, Liselotte Deroo: None declared, Triana Lobaton Ortega: None declared, Anne Hoorens: None declared, Philippe Carron: None declared, Filip van den Bosch Consultant for: AbbVie, BMS, Galapagos, Janssen, Lilly, Merck Novartis, Pfizer and UCB, Speakers bureau: AbbVie, BMS, Janssen, Lilly, Merck, Novartis, Pfizer and UCB., Dirk Elewaut: None declared DOI: 10.1136/annrheumdis-2019-eular.7797

\section{SAT0314 IMPLEMENTATION OF AN ASSESSMENT CHECKLIST FOR PATIENTS WITH SPONDYLOARTHRITIS IN DAILY PRACTICE}

Raquel Almodovar ${ }^{1}$, Beatriz Joven-lbáñez ${ }^{2}$, Esther Rodríguez Almaraz ${ }^{2}$, Sheila Melchor ${ }^{2}$, Elena Rabadan ${ }^{2}$, Virginia Villaverde ${ }^{3}, M^{\mathrm{a}}$ Teresa Navio, Laura Cebrian ${ }^{4}$, Leticia Lojo ${ }^{4}$, Alejandro Prada-Ojeda ${ }^{5}$, Laura González ${ }^{6}$, Álvaro García Martos ${ }^{6}$, Victoria Navarro-Compán ${ }^{7}$, Estíbaliz Loza ${ }^{8}$, Pedro Zarco-Montejo ${ }^{1}$. ${ }^{1}$ Fundación Hospital Alcorcón, Alcorcón, Spain; ${ }^{2}$ University Hospital 12 de Octubre, Madrid, Spain; ${ }^{3}$ Hospital de Móstoles, Móstoles, Spain; ${ }^{4}$ Hospital Universitario Infanta Leonor, Madrid, Spain; ${ }^{5}$ Hospital de Torrejón, Torrejón de Ardoz, Spain; ${ }^{6}$ Hospital del Tajo, Aranjuez, Spain; ${ }^{7}$ Hospital La Paz-madrid, Madrid, Spain; ${ }^{8}$ Instituto de Salud Musculoesquelética, Madrid, Spain

Background: Nowadays, despite international and national guidelines on the evaluation and management of spondyloarthritis $(\mathrm{SpA})$, several studies have depicted a sub-optimal assessment of these diseases.

Objectives: To analyze the feasibility and changes in the collection of clinical measures after the implementation in daily practice of a checklist designed for an optimal evaluation and monitoring of patients with SpA, including psoriatic arthritis (PSA).

Methods: An observational prospective study was performed. The feasibility of the assessment checklist (paper/on-line format) for patients with $\mathrm{SpA}$ was tested (time to complete the checklist, simplicity, amenity clarity, usefulness). Through a medical files review, changes in the number of the checklist variables collected were analyzed previous to the implementation of the checklist and 6 months later. A descriptive and bivariate analysis was performed.

Results: A total 6 hospitals and 11 rheumatologists participated. The median time to checklist completion was 15 (12-20) minutes, and the mean scores for the rest of variables of the feasibility test were in general positives, $6.9 \pm 1.1$ (simplicity) and $6.9 \pm 0.8$ (amenity), to $7.5 \pm 1.2$ (clarity) and $7.5 \pm 1.4$ (usefulness). A total of 83 and 68 medical files pre-implementation and post-implementation were reviewed respectively. Patient's features were similar. Mean age at diagnosis was $42.3 \pm 1.6$ and $40.3 \pm 1.3$ years respectively. In both study samples around a half of patients were men, and axial SpA and PsA were equally distributed as well $(40.2 \%$ and $44.8 \%$ pre- and post-implementation ( $47.6 \%$ and $47.8 \%)$. We observed a significant increase in the collection of many of the checklist variables after the implementation. The record of BASDAI increased from $46.2 \%$ to $73.1 \%$ $(\mathrm{p}=0.001)$, physical activity from $48.2 \%$ to $88.2 \% \quad(p<0.0001)$, physician global (VAS) from $28.0 \%$ to $73.5 \%(p<0.0001)$, patient global (VAS) from $48.8 \%$ to $85.3 \% \quad(p<0.0001)$, morning stiffness from $62.8 \%$ to $84.8 \%$ $(p=0.003$ ), ASDAS (in axial $\mathrm{SpA}$ ) from $12.2 \%$ to $32.8 \%(p=0.002)$, BASFI from $43.7 \%$ to $65.7 \%(\mathrm{p}=0.008)$, or DAS28 (in $\mathrm{PSA})$ from $24.7 \%$ to $46.3 \%$ $(p=0.006)$. The record of extra-articular symptoms and signs and all of the comorbidities but for osteoporosis and peptic ulcer significantly improved too. The percentage of change ranged from $20 \%$ (extra-articular symptoms and signs or arterial hypertension) to $30 \%$ (diabetes mellitus, hyperlipidemia, gout/hyperuricemia and renal failure. Other checklist variables increased but not significantly. However, some of them like the HLA-B27 or work status were already recorded (before the implementation of the checklist) in the $82.3 \%$ and $95.2 \%$ of medical files respectively. Changes were observed irrespectively of SpA classification.

Conclusion: The implementation of an assessment checklist in daily practice is feasible and improve the assessment of SpA patients.

Acknowledgement: To María Jesús García de Yébenes for her methodological support.

Disclosure of Interests: RAQUEL ALMODOVAR: None declared, Beatriz Joven-Ibáñez Speakers bureau: Celgene, Novartis, MSD, Pfizer, AbbVie, and Janssen, Esther Rodríguez Almaraz: None declared, Sheila Melchor: None declared, Elena Rabadan: None declared, Virginia Villaverde: None declared, $M^{\underline{a}}$ Teresa Navio: None declared, Laura Cebrian: None declared, Leticia Lojo: None declared, Alejandro Prada-Ojeda: None declared, Laura González: None declared, Álvaro García Martos: None declared, Victoria Navarro-Compán: None declared, Estíbaliz Loza Grant/ research support from: Roche, MSD, Pfizer, Abbvie, BMS, UCB, Actelion, Celgene, Grunenthal and Sanofi, Pedro Zarco-Montejo: None declared DOI: 10.1136/annrheumdis-2019-eular.3093 